\title{
Rhetorical Legitimation of the Asian Infrastructure Investment Bank: Evidence from Chinese State Media
}

\section{Hai Yang \& Stephan Keukeleire}

To cite this article: Hai Yang \& Stephan Keukeleire (2019): Rhetorical Legitimation of the Asian Infrastructure Investment Bank: Evidence from Chinese State Media, Journal of Contemporary China, DOI: $10.1080 / 10670564.2019 .1594105$

To link to this article: https://doi.org/10.1080/10670564.2019.1594105

+ View supplementary material

曲 Published online: 21 Mar 2019.

Submit your article to this journal

Lll Article views: 9

View Crossmark data $\nearrow$ 


\title{
Rhetorical Legitimation of the Asian Infrastructure Investment Bank: Evidence from Chinese State Media
}

\author{
Hai Yang (D) and Stephan Keukeleire (D) \\ Leuven International and European Studies, Faculty of Social Sciences, , KU Leuven, Belgium
}

\begin{abstract}
This research examines throughout the rhetorical efforts of Chinese state media to externally legitimate the AIIB. To that end, it builds an analytical framework of legitimacy comprising four general dimensions-external, institutional, procedural and performance, each of which is substantiated by legitimacy claims specific to the AlIB. Empirically, the article is based on an in-depth content analysis of 730 AllB-centric articles collected from four state media. The study finds the following: (1) Chinese state media grounded the AllB's justificatory rhetoric primarily on institutional legitimacy and external recognition, and more specifically, the bank's utility, complementarity, and growing membership/support; (2) Chinese state media intensified rhetorical efforts following the UK's announcement to join and increasing international attention on the new bank. The framework built and conclusions drawn herein can shed some light on China's rhetorical legitimation of its emerging institution-building behavior.
\end{abstract}

\section{Introduction}

The People's Republic of China (hereafter China) under President Xi Jinping is unfolding a distinct 'striving-for-achievement' foreign policy and seeking a greater status in the world order all the while remaining a stakeholder thereof. ${ }^{1}$ Among others, it has launched a series of high-profile institution-building initiatives. One of the most noteworthy and successful moves thus far is the Asian Infrastructure Investment Bank (AIIB). It was unveiled in October 2013 and materialized in January 2016. As of December 2018, the lending institution had boasted 93 members worldwide and approved 35 projects worth $\$ 7.5$ billion. $^{2}$

After the AllB was announced, China was keen to persuade other countries into joining in an effort to promote the legitimacy of the inchoate lender and transform it from a Chinese proposal into a real multilateral institution with global standing. Yet apart from some Asian and Middle Eastern countries, most leading economies early on decided to stay outside, wary of China's ulterior motives and the AllB's standards. As late as January 2015, the Group of Seven members in effect agreed not to join without a consensus. ${ }^{3}$ The legitimacy issue came into the limelight following the 'surprising' announcement of the United Kingdom (UK) to join on 12 March 2015, and perhaps

CONTACT Hai Yang hai.yang@kuleuven.be

${ }^{1}$ Xuetong Yan, 'From keeping a low profile to striving for achievement', Chinese Journal of International Politics 7(2), (2014), pp. 153-184; Suisheng Zhao, 'A revisionist stakeholder: China and the post-World War II world order', Journal of Contemporary China 27(113), (2018), pp. 643-658.

${ }^{2}$ Asian Infrastructure Investment Bank, 'Quick facts', www.aiib.org/en (accessed 19 December 2018).

${ }^{3}$ Jamil Anderlini, 'UK move to join China-led bank a surprise even to Beijing', Financial Times, (26 March 2015), available at: www.ft.com/content/d33fed8a-d3a1-11e4-a9d3-00144feab7de (accessed 12 September 2017).

(1) Supplemental data for the article can be accessed here. 
more importantly, the public disapproval expressed by the United States (US) of the UK's 'constant accommodation' with China.

Contestation, politicization and mediatization followed the UK's decision, triggering a 'framing contest' with different actors seeking to justify their stance vis-à-vis the new bank. ${ }^{4}$ Officially, the US, along with Japan, cited reservations about the AllB's standards for their cautious position. They reckoned that the lax safeguards of the China-led lending institution could erode the international best practices espoused by established multilateral development banks (MDB). Commenting on the AllB in the immediate wake of leading European powers' decisions to join, the then US Secretary of Treasury Jack Lew said, 'our concern has always been...will it adhere to the kinds of high standards that the international financial institutions have developed? Will it protect the rights of workers, the environment, deal with corruption issues appropriately? ${ }^{5}$ Unofficially, many contend the skepticism of Washington and Tokyo about the bank was mostly owed to two considerations. The first is the potential of the China-backed bank to compete and undermine the global financial establishment embodied by the US/Japan-dominated International Monetary Fund (IMF), WB and ADB. ${ }^{6}$ The second is the strong likelihood of China using the bank as a crude instrument to advance economic and political interests at the expense of others. ${ }^{7}$

Facing persistent suspicions from the US/Japan and following momentous decisions of several advanced economies to sign on, China 'capitulated' to some demands of the global community and readjusted its initial position on the AllB's membership, primary function, capital contribution, shareholding structure, governance and standards. ${ }^{8}$ Running in tandem with this was China's efforts to carefully craft and articulate an eclectic mix of justificatory discourse on the AllB for the purpose of discrediting rivaling claims and further legitimating the new MDB to its (potential) members and relative to its established peers. This heretofore un(der-)explored aspect is the focus of this study.

While recognizing the different sources available for studying Chinese official discourse, the study at hand focuses on Chinese state media, which arguably provided a more consistent and adequate coverage of the AllB than other sources (see infra). Equally, it zooms in on the external dimension of legitimation, given that the need to legitimate the AIIB was much more compelling externally than internally.

Accordingly, the research question is formulated as follows: how did Chinese state media seek to rhetorically legitimate the AIIB to the international community? To address this question, the study first draws insights from existing literature on legitimacy and sketches out an analytical framework comprising four general legitimacy dimensions: external, institutional, procedural and performance. Subsequently, the four-dimensional framework is contextualized within the AllB case and substantiated by legitimacy claims specific to the new bank. Finally, the case-specific framework is used to analyze a dataset of 730 AllB-focused texts selected from four Chinese state media outlets.

Before going any further, it is helpful to clarify two points regarding the objective and scope of the article. First, the study focuses exclusively on the rhetorical legitimation of the AllB, effectively complementing previous studies on China's substantive efforts to promote the AllB within the context of diplomatic exchanges and negotiations. ${ }^{9}$ Second, identifying the legitimacy claims ascribed to the AllB

\footnotetext{
${ }^{4} \mathrm{Hai}$ Yang and Baldwin Van Gorp, 'Framing the Asian Infrastructure Investment Bank: a qualitative analysis of the political debate and media coverage on a China-led multilateral institution', The Pacific Review, (2018), DOI: 10.1080/ 09512748.2018.1512647.

${ }^{5}$ US Department of the Treasury, 'Secretary Lew's hearing on the international financial system', (19 March 2015), available at: www.treasury.gov/connect/blog/Pages/Secretary-Lew's-Hearing-on-the-International-Financial-System.aspx (accessed 14 February 2018).

${ }^{6}$ Amitai Etzioni, 'The Asian Infrastructure Investment Bank: a case study of multifaceted containment', Asian Perspective 40(2), (2016), pp. 173-196; Philip Lipscy, 'Who's afraid of AllB', Foreign Affairs, (7 May 2015), available at: www.foreignaffairs.com/ articles/china/2015-05-07/whos-afraid-aiib (accessed 10 October 2017).

${ }^{7}$ Masahiro Kawai, 'Asian Infrastructure Investment Bank in the evolving international financial order', in Daniel Bob, ed., Asian Infrastructure Investment Bank: China as Responsible Stakeholder? (Washington DC: Sasakawa Peace Foundation USA, 2015), pp. 5-26.

${ }^{8}$ Yun Sun, 'China and the evolving Asian Infrastructure Investment Bank', in Daniel Bob, ed., Asian Infrastructure Investment Bank: China as Responsible Stakeholder? (Washington DC: Sasakawa Peace Foundation USA, 2015), pp. $27-41$.

${ }^{9}$ lbid.
} 
is not akin to saying that rhetorical legitimation was effective. This is because 'legitimacy claims are not necessarily accepted by legitimacy-granting audiences' and therefore, 'may or may not contribute to an institution's legitimacy in the eyes of relevant communities. ${ }^{10}$ This research does not aim to assess the effectiveness of China's legitimation, an issue worthy of study in its own right. In other words, it focuses on the intended messages and leaves out the reception thereof.

The remainder of the article is organized as follows. The first section situates the research in a broad context. The second section summarizes the legitimacy discussions and outlines a general framework of legitimacy. The third section explains the sample and the data analysis. The fourth section contextualizes the general framework in the AIIB and complements it with concrete legitimacy claims, followed by a section showing and interpreting the main findings. Lastly, some implications of the study and its limitations are discussed.

\section{Situating the research}

The study first and foremost features in the emerging scholarship on the AllB. Indeed, there have been a growing number of scholarly efforts at examining the recently-established bank from different perspectives. For the most part, extant works on the AllB can be divided into three strands. The first strand looks at the AlIB proper including its institutional continuities and innovations, voting power structure, accountability mechanism, staffing policy and social-environmental framework. ${ }^{11}$ The second category speculates about the implications of the new lender for the Bretton Woods institutions, multilateral development financing and global governance at large. ${ }^{12}$ The third and last branch discusses the plausible rationales driving China to establish the bank. ${ }^{13}$ This study takes a different tack and aims to analyze the rhetorical legitimation of the initiative. It does so by looking into the justificatory rhetoric as presented in Chinese state media.

Second, the study can be embedded in the ongoing debate on the growing latticework of parallel structures (in addition to the AlIB) to the existing international architecture backed by China alone or together with other emerging powers, most notably, but not limited to, the Belt and Road Initiative (BRI) and the New Development Bank (NDB). Extant studies have mainly examined the rationales for and the ramifications of these alternative structures. ${ }^{14}$ In this sense, the framework developed and the conclusions drawn herein-with due regard for caveat about generalizability—can shed light on

\footnotetext{
${ }^{10}$ Magdalena Bexell, 'Global governance, legitimacy and (de)legitimation', Globalizations 11(3), (2014), p. 293.

${ }^{11}$ Anton Malkin and Bessma Momani, 'An effective Asian Infrastructure Investment Bank: a bottom up approach', Global Policy 7(4), (2016), pp. 521-530; Bin Gu, 'Accountability mechanism: a perspective of AllB', Journal of World Trade 51(3), (2017), pp. 409-423; Chris Humphrey, 'Developmental revolution or Bretton Woods revisited?' Working Paper 418, (London: Overseas Development Institute, April 2015); Gregory T. Chin, 'Asian Infrastructure Investment Bank: governance innovation and prospects', Global Governance 22(1), (2016), pp. 11-25.

${ }^{12}$ Helmut Reisen, 'Will the AIIB and the NDB help reform multilateral development banking?', Global Policy 6(3), (2015), pp. 297-304; Hongying Wang, 'New multilateral development banks: opportunities and challenges for global governance', Global Policy 8(1), (2017), pp. 113-118; Paola Subacchi, 'The AllB is a threat to global economic governance', Foreign Policy, (31 March 2015), available at: foreignpolicy.com/2015/03/31/the-aiib-is-a-threat-to-global-economic-governance-china (accessed 12 September 2017); Rebecca Liao, 'Out of the Bretton Woods: how the AllB is different', Foreign Affairs, (27 July 2015), available at: www.foreignaffairs.com/articles/asia/2015-07-27/out-bretton-woods (accessed 12 July 2017).

${ }^{13} \mathrm{G}$. John Ikenberry and Darren J. Lim, 'China's emerging institutional statecraft: the Asian Infrastructure Investment Bank and the prospects for counter-hegemony', (Washington DC: Brookings Institution, 2017); Hai Yang, 'The Asian Infrastructure Investment Bank and status-seeking: China's foray into global economic governance', Chinese Political Science Review 1(4), (2016), pp. 754-778; Hong Yu, 'Motivation behind China's "One Belt, One Road" initiatives and establishment of the Asian Infrastructure Investment Bank', Journal of Contemporary China 26(105), (2017), pp. 353-368; Kevin G. Cai, 'The One Belt One Road and the Asian Infrastructure Investment Bank: Beijing's new strategy of geoeconomics and geopolitics', Journal of Contemporary China 27(114), (2018), pp. 831-847; Zheng Chen and Yanchuan Liu, 'Strategic reassurance in institutional contests: explaining China's creation of the Asian Infrastructure Investment Bank, Journal of Contemporary China 27(114), (2018), pp. 795-810.

${ }^{14}$ Andrew F. Cooper, 'The BRICS' New Development Bank: shifting from material leverage to innovative capacity', Global Policy, 8(3), (2017), pp. 275-284; James F. Paradize, 'The role of "parallel institutions" in China's growing participation in global economic governance', Journal of Chinese Political Science, 21(2), (2016), pp. 149-175; Sebastian Heilmann, Moritz Rudolf, Mikko Huotari and Johannes Buckow, 'China's shadow foreign policy: parallel structures challenge the established international order', China Monitor 18 (Berlin: Mercator Institute for China Studies, 28 October 2014); Weifeng Zhou and Mario Esteban, 'Beyond balancing: China's approach towards the Belt and Road Initiative', Journal of Contemporary China 27(112), (2018), pp. 487-501.
} 
another aspect of the issue under discussion, namely the legitimation of these additions to the incumbent global order.

Third, the study contributes to the broad debate about the legitimacy of international and regional organizations. Previous research in this field inclines towards established institutions subject to critical public review, not least the United Nations Security Council, the IMF, the WB, the World Trade Organization (WTO) and the European Union (EU). ${ }^{15}$ Indeed, scholars have produced granular analysis wherein they evaluate an institution's legitimacy against a set of normative yardsticks developed in democratic theory or by studying the perception of its stakeholders. This study is different in two aspects. First, it looks at a new institution and how it was rhetorically legitimated. Second, it is interested in drawing out the dynamics of legitimation rather than seeking to gauge the extent to which an institution is legitimate normatively or perceptively.

\section{Analytical framework: legitimacy}

Notwithstanding conceptual plurality, legitimacy is generally understood to have two aspectsempirical and normative. ${ }^{16}$ In an empirical sense, it is constituted by 'societal acceptance of political decisions and political orders. ${ }^{17}$ As such, the attribution/withdrawal of legitimacy hinges on subjective beliefs and perceptions. By contrast, normative legitimacy is defined as 'a generalized ... assumption that the actions of an entity are desirable, proper, appropriate within some socially constructed system of norms, values, beliefs, and definitions. ${ }^{18}$

Still, some scholars argue such purely empirical (legitimacy as perception) or normative (legitimacy as property) definitions are untenable and suggest instead a conceptualization that includes both normative and empirical aspects. For instance, Habermas postulates that 'legitimacy means that there are good arguments for a political order's claim to be recognized as right and just; a legitimate order deserves recognition. ${ }^{19}$ Similarly, Beetham surmises that it is imperative to take account of both people's beliefs and societal norms when discussing legitimacy. ${ }^{20}$ Deephouse et al. appear to subscribe to the same view, describing legitimacy as 'the perceived appropriateness of an organization to a social system in terms of rules, values, norms, and definitions' (emphasis added). ${ }^{21}$

In addition to the prevailing empirical-normative dichotomy, it is commonplace to make another two distinctions concerning legitimacy. First, while evaluating the legitimacy and effectiveness of the EU's multi-level governance, Scharpf makes a distinction between input legitimacy and output legitimacy. In essence, input legitimacy is process-oriented and relates to whether decisions are made based on procedures that respect widely accepted democratic principles, whereas output legitimacy is result-oriented and focuses on actual performance. ${ }^{22}$ The second

\footnotetext{
${ }^{15}$ Andrew Moravcsik, 'Reassessing legitimacy in the European Union', Journal of Common Market Studies 40(4), (2002), pp. 603-624; Cecilia Albin, 'Using negotiation to promote legitimacy: an assessment of proposals for reforming the WTO', International Affairs 84(4), (2008), pp. 763-765; Erik Jones, 'Output legitimacy and the global financial crisis: perceptions matter', Journal of Common Market Studies 47(5), (2009), pp. 1085-1105; lan Hurd, After Anarchy: Legitimacy and Power in the United Nations Security Council (Princeton: Princeton University Press, 2008); Ngaire Woods, 'Making the IMF and the World Bank more accountable', International Affairs 77(1), (2001), pp. 83-100; Martin Binder and Monika Heupel, 'The legitimacy of the UN Security Council: evidence from recent General Assembly debates', International Studies Quarterly 59(2), (2015), pp. 238-250.

${ }^{16}$ Allen Buchanan and Robert O Keohane, 'The legitimacy of global governance institutions', Ethics \& International Affairs 20(4), (2006), pp. 405-437.

${ }^{17}$ Michael Zürn, 'Global governance and legitimacy problems', Government and Opposition 39(2), (2004), p. 260.

${ }^{18}$ Mark C. Suchman, 'Managing legitimacy: strategic and institutional approaches', Academy of Management Review 20(3), (1995), p. 574.

${ }^{19}$ Jürgen. Habermas, Communication and the Evolution of Society, trans. Thomas McCarthy (Boston: Beacon Press, 1979), pp. 178-179.

${ }^{20}$ David Beetham, The Legitimation of Power (Houndsmills: Palgrave Macmillan, 1991), p. 11.

${ }^{21}$ David L. Deephouse, Jonathan Bundy, Leigh P. Tost and Mark C. Suchman, 'Organizational legitimacy: six key questions', in Royston Greenwood, Christine Oliver, Thomas Lawrence and Renate Meyer, eds., The SAGE Handbook of Organizational Institutionalism (Thousand Oaks, CA: Sage Publications, 2017), p. 32.

${ }^{22}$ Fritz W. Scharpf, Governing in Europe: Effective and Democratic? (Oxford: Oxford University Press, 1999).
} 
distinction is between internal legitimacy and external legitimacy. At the risk of oversimplifying, the former looks at legitimacy through the lens of state-citizenry dynamics, while the latter views legitimacy beyond states, often alluding to the recognition of statehood or actorness. ${ }^{23}$

Legitimacy is also a pivotal concept in organizational institutionalism and legitimation part and parcel of the discussion on institutional development and change. ${ }^{24}$ In the dynamic research on organizational legitimacy and institutional change, scholars have identified not only the various sources that confer legitimacy-states and state agencies, public opinion, news media, social movements, interest groups and individuals, but the different ideal-type criteria for gauging legitimacy-standards, performance, values and meaning systems. ${ }^{25}$ Clearly, a legitimating process can include a number of criteria to elicit more favorable judgements from relevant stakeholders.

Straddling traditional dividing lines, this study develops an analytical framework of legitimacy comprized of four aspects-external, institutional, procedural and performance. Important to point out that this framework, based on existing literature, is built as such that it increases the likelihood of capturing and comprehending all the legitimacy claims attributed to the AllB. Equally important, the research involves three distinct but partially overlapping concepts: legitimacy, legitimation and legitimacy claims. According to Reus-Smit, legitimacy is a desired property ascribed to the identities and practices of an actor or the norms, rules and principles of an institution; legitimation describes the process or practice whereby actors seek legitimacy by making legitimacy claims anchored in a wide range of possible legitimacy sources. ${ }^{26}$ For the sake of clarity and consistency, this research follows such a distinction.

\section{External dimension}

The first source of legitimacy is for third parties to recognize an actor or an institution and therefore confer legitimacy on it. As discussed earlier, (empirical) legitimacy is a matter of perception, and the recognition of states and other international actors is an essential source from which to derive legitimacy. In a four-dimensional 'actorness' conceptualization, Jupille and Caporaso incorporate external recognition, understood as 'acceptance of and interaction with the entity by others', as the sine qua non of actorhood. ${ }^{27}$ For them, external recognition comes in two variants-de jure and de facto. de jure recognition can be expressed either via diplomatic recognition pursuant to the provisions of international law or formal accession to international organizations/agreements. de facto recognition is achieved when third parties, state and non-state alike, decide to interact with the actor in question, thereby recognizing its actorhood implicitly. Such an account, it can be argued, is relevant for the discussion on legitimacy. This is because external recognition, albeit not correlated with legitimacy, is such a necessary condition that only actors and institutions enjoying broad recognition are seen as a legitimate authority. ${ }^{28}$

\section{Institutional dimension}

The second base for legitimacy relates to the theoretical construct of institutional innovation rooted in institutional theory. As said earlier, legitimation is essential to institutional change. It is

\footnotetext{
${ }^{23}$ Joseph Jupille and James A. Caporaso, 'States, agency, and rules: the European Union in global environmental politics' in Carolyn Rhodes, ed., The European Union in the World Community, (Boulder, CO: Lynne Rienner, 1998), pp. 213-229; Allen Buchanan, 'Recognitional legitimacy and the state system', Philosophy \& Public Affairs 28(1), (1999), pp. 46-78.

${ }^{24}$ Monica A. Zimmerman and Gerald J. Zeitz, 'Beyond survival: Achieving new venture growth by building legitimacy', Academy of Management Review 27(3), (2002), pp. 414-431; Roy Suddaby and Royston Greenwood, 'Rhetorical strategies of legitimacy', Administrative Science Quarterly 50.1, (2005), pp. 35-67; Derek Harmon, Sandy Green, and Thomas Goodnight, 'A model of rhetorical legitimation: the structure of communication and cognition underlying institutional maintenance and change', Academy of Management Review 40(1), (2015), pp. 76-95.

${ }^{25}$ Deephouse et al., 'Organizational legitimacy: six key questions'.

${ }^{26}$ Christian Reus-Smit. 'International crises of legitimacy', International Politics 44(2), (2007), p. 159.

${ }^{27}$ Jupille and Caporaso, 'States, agency, and rules', p. 214.

${ }^{28}$ Joseph Raz, Ethics in the Public Domain: Essays in the Morality of Law and Politics (Oxford: Clarendon, 1995), p. 356.
} 
a process by which legitimating actors invoke an array of legitimacy sources to make a case for the raison d'être of an institutional innovation. According to Raffaelli and Glynn, an institutional innovation should be a 'novel, useful and legitimate change'; legitimacy-being normatively and empirically legitimate-is inter-related with novelty and usefulness, which are two defining features of innovation in general. ${ }^{29}$ Based on the empirical data and the key premise of institutional isomorphism, this study adds complementarity to the institutional dimension. ${ }^{30}$ It is well known that underlying tensions exist between established institutions and new arrivals, with 'one accounting for the stability of social systems and the other for change. ${ }^{\prime 31}$ Institutional innovation is less likely to meet bitter resistance from actors bent on preserving institutional stability or stasis if it is (perceived) as an incremental change that is complementary to existing institutions and conforms largely to the prevailing institutional designs and practices instead of seeking to defy and subvert the current system.

\section{Procedural dimension}

The third criterion, which has a direct bearing on the input legitimacy, is procedure. As Albin notes in the assessment of efforts at reforming the WTO, a crucial component to procedural legitimacy is fair participation, equal representation and treatment of all parties in all stages of negotiation. ${ }^{32}$ Relating to discussions on deliberative democracy, insofar as institutions respect and promote accepted principles such as transparency, responsiveness, accountability, active stakeholder participation and deliberation, they are considered as legitimate, at least on the input side. ${ }^{33}$ Concerning legality, institutions would do well to 'act in accordance with their own secondary rules, to which states have consented and which determine who has the right to exercise authority, according to whatever procedures have been established, and subject to whatever limits have been determined. ${ }^{34}$ An institution's legitimacy will be called into question if negotiation and decision-making processes are undemocratic, unaccountable, unlawful or skewed to favor the interests of dominant actors at the expense of weak ones.

\section{Performance dimension}

The fourth aspect of legitimacy is grounded on performance. In many cases, state or non-state actors use actual performance-demonstrated ability to tackle problems and realize goals-to show governability and seek legitimacy. ${ }^{35}$ According to Gutner and Thompson, performance concerns 'both the outcome produced and the process-the effort, efficiency and skill-by which goals are pursued by an individual and organisation. ${ }^{36}$ As for the capacity to deliver, an international institution is often chartered as a functional mechanism to execute a specific mandate. Its legitimacy is thus contingent on whether and the extent to which it is capable of achieving agreed-on goals and solving problems that require collective action. As Buchanan and Keohane

\footnotetext{
${ }^{29}$ Ryan Raffaelli and Mary A. Glynn, 'Institutional Innovation: novel, useful, and legitimate', in Christina Shalley, Michael A. Hitt and Jing Zhou, eds., The Oxford Handbook of Creativity, Innovation, and Entrepreneurship (Oxford: Oxford University Press, 2015), pp. 413-414.

${ }^{30}$ Paul DiMaggio and Walter W. Powell. 'The iron cage revisited: institutional isomorphism and collective rationality in organizational fields', in Walter W. Powell and Paul DiMaggio, eds., The New Institutionalism in Organizational Analysis (Chicago: University of Chicago Press, 1991), pp. 63-82.

${ }^{31}$ Andrew B. Hargadon and Yellowlees Douglas, 'When innovations meet institutions: Edison and the design of the electric light', Administrative Science Quarterly 46(3), (2001), p. 476.

${ }^{32}$ Albin, 'Using negotiation to promote legitimacy', p. 760.

${ }^{33}$ John S. Dryzek, Deliberative Democracy and Beyond (Oxford: Oxford University Press, 2000).

${ }^{34}$ Binder and Heupel, 'The legitimacy of the UN Security Council', p. 241.

${ }^{35}$ Yuchao Zhu, 'Performance legitimacy and China's political adaptation strategy', Journal of Chinese Political Science 16(2), (2011), pp. 123-140.

${ }^{36}$ Tamar Gutner and Alexander Thompson, 'The politics of 10 performance: a framework', The Review of International Organizations 5(3), (2010), p. 231.
} 
aptly put it, 'If an institution cannot effectively perform the functions to justify its existence, then this insufficiency undermines its claim to the right to rule. ${ }^{37}$ The second element of performance is the process, namely how a task is accomplished. This requires the institution to be equipped with what it entails to execute the mandate and bridge the rhetoric-capability gap that so often results in poor performance evaluations and crises of credibility and legitimacy. Needless to say, an efficient institution with high standards and capable staff is more likely to outperform its peers.

\section{Data and method}

\section{Sample}

The study selected four Chinese state media: Xinhua News Agency (hereafter Xinhua), People's Daily $(P D)$, China Daily $(C D)$ and Global Times $(G T)$. They were chosen for three reasons. First, this study sets out to examine Chinese official discourse, which offers 'the framework within which policy and initiatives are developed, explained and legitimated both domestically and internationally. ${ }^{38}$ In general, Chinese media, although incrementally diversifying following marketization, remains 'structurally and editorially subject to control by the propaganda departments of different levels of the Communist Party of China. ${ }^{39}$ In particular, state media are known to be the mouthpiece of the Party-State, contributing to constructing and establishing political reality. Hence their viewpoints, albeit with room for manoeuvre, fall in line with the official discourse. As a matter of fact, a host of studies have used state media as a way of analyzing Chinese official rhetoric. ${ }^{40}$

Second, state media were prioritized over other sources such as official documents and statements. At the official level, primary sources from Chinese officialdom dealing mostly or exclusively with the AllB were rather limited and piecemeal. Meanwhile, Chinese state media not only had a readily-available and consistent coverage of China's AllB rhetoric-allowing a closer look at the content and evolution of the rhetorical legitimation, but also incorporated the perceptions and responses of third parties such as representatives of foreign governments and international institutions-a dimension integral to the legitimacy discussion. Third, given this study's focus on external legitimation, four news outlets targeting foreign audiences were chosen: Xinhua (English edition), PD (English edition), GT (English edition) and English-language CD.

The timeframe under consideration spans from early October 2013-when the AllB was unveiled, till December 2017-roughly two years after the bank's official establishment. All the articles appearing in these four news outlets during this period on the AllB were selected and reviewed. ${ }^{41}$ Given the research's overarching aim, only those treating the AllB as the primary subject were retained. This means articles mentioning the AllB in passing, for example, within the context of the BRI or China's relationship with third countries, were systematically excluded. In the end, a total of 730 articles were included.

One notable characteristic of the sample is the uneven distribution by source and over time (Table 1). In terms of the distribution by source, Xinhua was the most dominant. This results in part from the order of data collection. Articles from Xinhua were gathered before the other three newspapers, which reproduced and forwarded a considerable number of texts from the official news agency. To avoid duplication, all the reproduced/forwarded texts in the three newspapers

\footnotetext{
${ }^{37}$ Buchanan and Keohane, 'The legitimacy of global governance institutions', p. 422.

${ }^{38}$ Julia C. Strauss, 'Framing and Claiming: contemporary globalization and "going out" in China's rhetoric towards Latin America', The China Quarterly 209, (2012), p. 136.

${ }^{39}$ Haiyan Wang, Colin Sparks, Nan Lü and Yu Huang, 'Differences within the mainland Chinese press: a quantitative analysis', Asian Journal of Communication 27(2), (2017), p. 154.

${ }^{40}$ Li Zhang, "'Reflexive expectations" in EU-China relations: a media analysis approach', Journal of Common Market Studies 54(2), (2016), pp. 463-479; Yew-Jin Fang, 'Reporting the same events? A critical analysis of Chinese print news media texts', Discourse \& Society 12(5), (2001), pp. 585-613; Chiung Hwang Chen, 'Framing Falun Gong: Xinhua news agency's coverage of the new religious movement in China', Asian Journal of Communication, 15(1), (2005), pp. 16-36.

${ }^{41}$ All the texts were taken from the database LexisNexis except for those from GT, which were taken from the website www. globaltimes.cn. Effective data started from 7 March 2014 and ended in 17 December 2017.
} 
Table 1. Breakdown of news articles

\begin{tabular}{lccccc}
\hline & 2014 & 2015 & 2016 & 2017 & Total \\
\hline Xinhua & 30 & 231 & 84 & 52 & 397 \\
Global Times & 10 & 77 & 23 & 14 & 124 \\
China Daily & 7 & 79 & 16 & 14 & 116 \\
People's Daily & 0 & 37 & 29 & 27 & 93 \\
\hline
\end{tabular}

were excluded. For the distribution over time, the year of 2015, especially March 2015, saw a spike in the number of articles on the AIIB by the four news sources-an aspect that will be further discussed later.

\section{Data analysis}

The coding was done in three steps. First, a provisional coding scheme was developed via an abductive approach, which means initial codes were refined repeatedly in a preliminary data analysis. Second, as often required in qualitative content analysis, a test phase was conducted wherein the authors coded 80 articles (about $10 \%$ of the total) with a view to refining the coding scheme. After obtaining solid intercoder reliability and thus assuring the validity of the coding scheme, one author completed the coding of remaining texts. ${ }^{42}$ Substantively, each article was coded categorically on the 11 legitimacy claims (see infra) that fall under the four general dimensions. After reading through the article, the coder was asked to decide which dimension is the most dominant in toto. The main criterion for weighing the salience of each dimension is the frequency of claims. In case of ambiguity, the article's headline and lead paragraph are used as the main point of reference.

Before proceeding further, it is necessary to mention two points about the coding process. First, although an absolute majority of the texts in the sample presented the AIIB in a positive light, there were a smattering of articles that were written not to legitimate but to discuss the problematic aspects of the institution in-the-making or make some swipes at AllB critics and naysayers. For these cases, the legitimacy claims present were still coded but the predominant dimension was not. Second, an article may refer to one claim several times, but this study only codes once per claim per article. Such an approach is supplemented by the second step of coding. For example, repeated references in a text to the AIIB being a complement to other MDBs is likely to result in the coding of 'institutional' as dominant.

\section{Contextualizing legitimacy in the AllB: 11 legitimacy claims}

Building on an in-depth content analysis of the empirical data, the four general legitimacy dimensions-external, institutional, procedural and performance-are substantiated by 11 legitimacy claims specific to the AlIB (Table 2).

\section{AIIB: 'well received and supported by the international community'}

In the AlIB context, external dimension refers to both formal participation and informal endorsement. The former is expressed via the formal decisions of third parties to participate in the AllB by applying for membership, and later on signing and ratifying the Articles of Agreement (AoA). The latter is defined in a broader sense. It concerns deliberate actions of states that intimate recognition, ranging from signalling interest to join (as yet undetermined or unable to submit a membership application) or changing position from dismissal/doubt to welcome/participation. After the AllB's announcement in late 2013, China started actively to lobby other countries to partake. However, the gesture was not reciprocated by major powers early on. The situation took a dramatic turn when the UK decided to

\footnotetext{
${ }^{42} \mathrm{~A}$ kappa value of above 0.75 was obtained before carrying out remaining coding. Coding scheme is available on request.
} 
Table 2. Legitimacy in the AllB context

\begin{tabular}{|c|c|c|}
\hline $\begin{array}{l}\text { Legitimacy } \\
\text { dimension }\end{array}$ & Legitimacy source & Legitimacy claim \\
\hline \multirow[t]{2}{*}{ External } & Formal participation & A growing number of countries have applied to join AllB. \\
\hline & Informal endorsement & $\begin{array}{l}\text { Third parties have expressed interest in joining or shifted stance from dismissal } \\
\text { to engagement. }\end{array}$ \\
\hline \multirow[t]{3}{*}{ Institutional } & Usefulness & $\begin{array}{l}\text { AllB provides needed infrastructure investment and every party involved stands } \\
\text { to benefit. }\end{array}$ \\
\hline & Complementarity & $\begin{array}{l}\text { AllB is a complement to the existing multilateral financing institutions such as } \\
\text { the WB and ADB. }\end{array}$ \\
\hline & Legitimate change & AllB is a welcome alternative to the problematic prevailing lending practices. \\
\hline \multirow[t]{3}{*}{ Procedural } & Openness & AllB welcomes all the parties interested and its door will always stay open. \\
\hline & Equality & $\begin{array}{l}\text { AllB decision-making is to be based on equality, and China will not exercise de } \\
\text { facto veto power. }\end{array}$ \\
\hline & Legality & AIIB is to be formally established after it meets two conditions. \\
\hline \multirow[t]{3}{*}{ Performance } & Staffing & $\begin{array}{l}\text { AllB adopts merit-based universal recruitment and boasts an excellent } \\
\text { management team. }\end{array}$ \\
\hline & Standards & $\begin{array}{l}\text { AllB upholds high international standards and cultivates a 'lean, clean, green' } \\
\text { modus operanti. }\end{array}$ \\
\hline & Actual operation & AllB has unfolded operations smoothly and got three triple-A ratings. \\
\hline
\end{tabular}

come on board, followed by France, Germany, Italy, South Korea, Australia and a bevy of states in and beyond Asia. Interest in AllB membership has sustained until now, and the bank has continued to receive membership applications after its official establishment. 'Better-than-expected' participation, along with the shift of stance by some governments such as the US and Australia, was shown as evidence of the growing and extensive support for the AllB and used to bolster other claims such as the bank's usefulness, complementarity and respectable governance. ${ }^{43}$

\section{AllB: 'useful, complementary, and represents a welcome change'}

Pertaining to the AIIB as a new institution, institutional dimension points to an inter-related triad of usefulness, complementarity and legitimate change. ${ }^{44}$ First, the new lender, with its $\$ 100$ billion of authorized capital earmarked for Asian infrastructure and potential to leverage more funding from the private sector, was feted as a solution to the underdeveloped infrastructure that has long hindered connectivity, economic growth and poverty reduction in Asia and beyond. ${ }^{45}$ In addition, investors and companies of AllB members are able to reap benefits by investing in major infrastructure projects in Asia. A related second point is that the AllB was framed as a complement/ supplement to established MDBs such as the WB and the ADB, working alongside them rather than weakening them. ${ }^{46}$ It has in effect engaged in cofinancing partnerships with several established MDBs. ${ }^{47} \mathrm{~A}$ third element is that the AllB was evoked as a welcome change vis-à-vis the 'problematic' status quo. The world's newest MDB, headed by emerging economies, was framed as an important step towards reforming global economic governance that has so far failed to reflect the evolving economic reality. ${ }^{48}$ Equally, the AlIB was branded as a credible alternative endowed with

\footnotetext{
${ }^{43 \prime}$ AllB attracts global support', Global Times, (1 April 2015), available at: www.globaltimes.cn/content/914893.shtml (accessed 1 June 2017); 'AllB approves 13 new applicants, expands membership to 70', Xinhua, (23 March 2017), available at: www. xinhuanet.com//english/2017-03/23/C_136151044.htm (accessed 10 May 2017); 'More nations set to join AllB', Global Times, (29 March 2015), available at: www.globaltimes.cn/content/914496.shtml (accessed 1 May 2017).

${ }^{44}$ Usefulness refers to an ex ante statement of utility and necessity, as distinct from ex post performance.

${ }^{45}$ 'Establishment of AllB to bring myriad of advantages', China Daily, (4 April 2015), available at: global.chinadaily.com.cn/ business/2015-04/04/content_20000920.htm (accessed 10 May 2017).

${ }^{46}$ AllB complementary to ADB, World Bank: Chinese finance minister', People's Daily, (24 October 2014), available at: en.people. $\mathrm{cn} /$ business/n/2014/1024/c90778-8799685.html (accessed 5 May 2017).

${ }^{47}$ 'AllB to explore cooperation to finance investment projects', China Daily, (9 May 2016), available at: www.chinadaily.com.cn/ business/2016-05/09/content_25146411.htm (accessed 10 May 2017).

${ }^{48} \mathrm{Xi}$ eyes better global financial governance as MOU signed on new multilateral bank', Xinhua, (24 October 2014), available at: www.chinadaily.com.cn/business/2014-10/24/content_18799628.htm (accessed 5 May 2017).
} 
distinct characteristics (e.g. non-resident Board of Directors) designed to overcome some of the structural problems confronting its established peers. ${ }^{49}$

\section{AllB: 'open to all, collective decision-making, legally established'}

Procedural dimension introduces three aspects that are linked to open membership, equal decisionmaking and legality of the AIIB. First, it was emphasized that the multilateral lender would welcome all the parties interested to participate and that the door would stay open after its official establishment. $^{50}$ This applies to (perceived) strategic rivals of China such as Japan and the US, neighboring countries embroiled in disputes with China in the South China Sea represented by Vietnam and Philippines, least-developed economies including Cambodia and Nepal, and nonsovereign entities such as Hong Kong and Taiwan. The principle of inclusive and open participation is relevant for the legitimacy discussion in that the entry of Japan and the US, for example, would seriously dilute China's shareholding and reduce its ability to use the AllB for narrow economic and political ends. The second aspect touches upon equality in the AlIB's rule-making and decisionmaking processes. The institutional set-up and the AoA were showcased as a result of collective efforts of all the founding members, which engaged in extensive consultations and eight rounds of multilateral negotiations (Chief Negotiators' Meetings) rather than dictated by Beijing. ${ }^{51}$ In addition, China will not use de facto veto power and decisions on day-to-day operation will be made by consensus. ${ }^{52}$ A third procedural issue concerns the two preconditions for the AoA to be legally valid and the AIIB to be formally established. That is, no less than 17 founding members obtain parliamentary approval of the AoA, and they have to represent at least $50 \%$ of the total subscribed capital. $^{53}$

\section{AIIB: 'respectable staff, high-standard, strong performance'}

Performance dimension focuses on three aspects: staffing, standards and operation of the bank. Given the AllB's specificity, both its actual performance since mid-January 2016 and expected performance before that were taken into consideration. First, in terms of staffing, its President Jin Liqun was lauded as an experienced technocrat with outstanding leadership and management skills and its five Vice-Presidents were extoled as 'an exceptionally strong and committed group who will bring wide and varied experience and a wealth of expertise that will serve the bank well. ${ }^{54}$ Relatedly, the merit-based and universal recruitment was also highlighted. ${ }^{55}$ Second, on governance and lending standards, it was reiterated that the AllB would uphold the highest international standards by cultivating a modern modus operanti of 'lean, clean and green' and funding only 'high quality, financially viable and environmentally friendly' projects. ${ }^{56}$ Finally, the AllB's actual operation since its establishment, above all the fulfilment of self-imposed loan targets

\footnotetext{
${ }^{49}$ 'China gets 30\% stake in AllB as bank takes shape', China Daily, (29 June 2015), available at: www.chinadaily.com.cn/bizchina/ 2015-06/29/content_21130572.htm (accessed 5 May 2017).

${ }^{50}$ 'China welcomes all countries to join the AllB', Xinhua, (25 March 2015), available at: www.xinhuanet.com/english/2015-03/ 25/c_134096617.htm (accessed 5 May 2017).

51'AIIB chief rules out China veto power', China Daily, (27 January 2016), available at: www.chinadaily.com.cn/business/2016-01/ 27/content_23265846.htm (accessed 5 May 2017).

${ }^{52 ،}$ Inclusive AllB can make a difference', China Daily, (25 June 2015), available at: www.chinadaily.com.cn/bizchina/2015-06/25/ content_21098721.htm (accessed 5 May 2017).

${ }^{53}$ 'Key legal framework laid for China-initiated AllB', Xinhua, (28 June 2015), available at: www.xinhuanet.com/english/2015-06/ 29/c_134364744_5.htm (accessed 10 May 2017).

${ }^{54}$ AIIB appoints senior leadership team', Xinhua, (5 February 2016), available at: www.xinhuanet.com/english/2016-02/05/C 135078869.htm (accessed 10 May 2017).

${ }^{55}$ 'AllB appointments based on qualification, funding', Global Times, (13 February 2016), available at: www.globaltimes.cn/ content/968274.shtml (accessed 1 June 2017).

${ }^{56}$ 'AllB will uphold high standards', China Daily, (29 April 2015), available at: www.chinadaily.com.cn/business/2015-04/29/ content_20575131.htm (accessed 5 May 2017); 'AllB expands membership', Xinhua, (23 March 2017), available at: www. xinhuanet.com/english/2017-03/23/c_136152662.htm (accessed 5 May 2017).
} 
and the receipt of three triple-A credit ratings, was used to demonstrate the bank's strong business profile and promising prospects. ${ }^{57}$

Taken together, the 11 legitimacy claims coalesce to constitute the building blocks of the legitimating discourse on the AllB by Chinese state media. They bear out the raison d'être of the new lender and translate its creation into a 'positive, beneficial, ethical, understandable, necessary, or otherwise acceptable action. ${ }^{58}$ A corollary question arises: what role did each of 11 claims (and by extension, four dimensions) play in the legitimation, respectively? In what follows, the study presents the main findings of an empirical inquiry in which each of the 730 articles was analyzed along the lines of the purpose-built framework.

\section{Relative weight and evolution of legitimacy dimensions and legitimacy claims}

\section{Finding (1): institutional and external as prominent legitimacy dimensions}

The first finding concerns the distribution of overall references to the four dimensions, that is, the dominant dimension of each article. As shown below (Figure 1, left), Chinese state media grounded the AllB's legitimacy mostly on the institutional and external dimensions. Among the 658 (out of 730) articles wherein a dominant dimension was identified, $44 \%$ made claims primarily related to the institutional dimension and $35 \%$ to the recognition of third parties. Furthermore, the salience of these two dimensions is evident over time (Figure 1, right).

The dominance of the institutional dimension is remarkable but little surprising. After all, the AllB was proposed as an institutional solution to the widely acknowledged financing gaps in Asian infrastructure and was legitimated vis-à-vis established MDBs. Aside from prevalent and repeated references to the utility of the AllB for Asian infrastructure and the potential benefits the bank can generate for its stakeholders, the high co-occurrence of the institutional triad (usefulness, complementarity, legitimate change) effectively increases the likelihood of coding 'institutional' as the dominant dimension. This comment is a case in point. 'The bank is set to finance massive infrastructure projects in Asia and meet the growing demand for a more inclusive and balanced international financial order...[and] complements the existing rules of global finance. ${ }^{59}$

As for the relative salience of external dimension, two factors could be at play. First, as an institution in-the-making, the AllB was rather long on rhetoric and short on specifics. It was unable to dispel convincingly legitimate concerns of third actors. External recognition, both formal and informal, was thus often presented as a validation of the AllB and what it is supposed to do or look like. As said here, 'Canada's joining illustrates worldwide recognition of China's efforts to improve economic and social development in Asia by investing in high quality, financially viable and environmentally friendly infrastructure projects. ${ }^{60}$ Similarly, US's 'apparent change of mind from its earlier suspicion and obstruction ... [is] indicative of the attractiveness and all-win nature of the incipient institution. ${ }^{61}$ Second, the AIIB has been one of China's most noteworthy multilateral moves under President Xi. In view of its global ambitions and ramifications, the new bank was initially frowned upon and heavily contested. Recognition of third parties-not least major Western powers and international institutions -was highly valued and sought after, since it could serve not only to counter the allegations of AllB

\footnotetext{
57،AllB completes hat trick of global AAA ratings', People's Daily, (19 July 2017), available at: en.people.cn/business/n3/2017/ 0719/c90778-9243829.html (accessed 30 July 2017); 'AllB poised to meet loan targets', Global Times, (25 June 2016), available at: www.globaltimes.cn/content/990472.shtml (accessed 1 June 2017).

${ }^{58}$ Eero Vaara, 'Struggles over legitimacy in the eurozone crisis: discursive legitimation strategies and their ideological underpinnings', Discourse \& Society 25(4), (2014), p. 503.

${ }^{59}$ 'The world votes for AllB, new economic order', China Daily, (1 April 2015), available at: www.chinadaily.com.cn/business/ 2015-04/01/content_19974351.htm (accessed 5 May 2017).

${ }^{60}$ AllB welcomes 13 new prospective members', CD, (24 March 2017), available at: www.chinadaily.com.cn/business/2017-03/ 24/content_28658916.htm (accessed 5 May 2017).

${ }^{61}$ Washington's U-turn on AllB: Moral epiphany, or Machiavellian ploy?' People's Daily, (24 March 2015), available at: en.people. $\mathrm{cn} / \mathrm{n} / 2015 / 0324 / \mathrm{c} 90883-8867990 . h t m l$ (accessed 10 May 2017).
} 

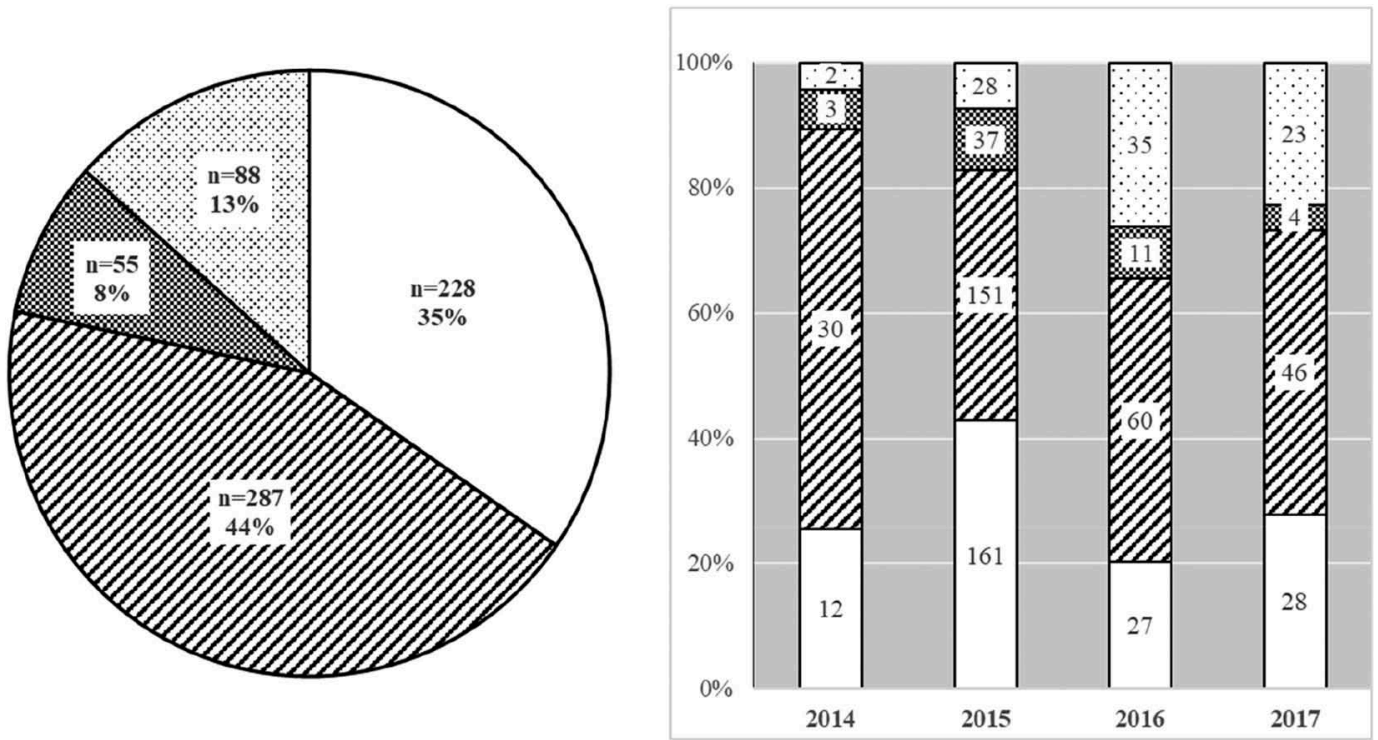

口External DInstitutional

Drocedural

口Perform ance

Figure 1. Distribution of references to legitimacy dimension.

naysayers and tilt the discussion in China's favor, but more important, to drum up more support from the international community and boost the legitimacy of the fledgling bank.

\section{Finding (2): utility, external participation, complementarity and standards as core claims}

The respective weight of overall references to the four legitimacy dimensions brings to the fore the prominence of the institutional and external dimensions. Still, an overview on the aggregate level cannot unmask the more nuanced configuration of legitimating discourse underpinned by key claims. This sub-section presents a more detailed distribution of the 11 legitimacy claims. As illustrated in Figure 2, usefulness, growing participation and complementarity took the lead, mentioned in $72 \%, 59 \%$ and $43 \%$ of the texts, respectively. References to standards came fourth, which is somewhat surprising, as the performance dimension does not feature largely in the overall distribution. The same holds true, albeit to a lesser degree, for the number of references to equality, operations and openness.

Although the prominence of usefulness, growing participation and complementarity can be explained by the same factors that contributed to the dominance of institutional and external dimensions, their high frequency is inextricably bound up with the inter-relationality between the three claims. As stated earlier, external recognition was often invoked as an approval of the AllB and how it is supposed to be. This is particularly true for its usefulness and complementarity. The following remark is a case in point. The AllB is 'an additional source of investment for countries in need. That is why Chancellor George Osborne put the AllB's role as complementary to other funding institutions, and why heads of both the WB and ADB welcome the entry of the AllB. ${ }^{162}$ A rather common follow-up claim is that states joined the AllB precizely because of their belief in the bank's potential to bring business opportunities, which was also coded as 'usefulness' in the form of beneficial consequence. As said here, 'it is only natural for major European economies like

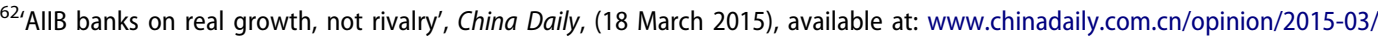
18/content_19839189.htm (accessed 5 May 2017).
} 


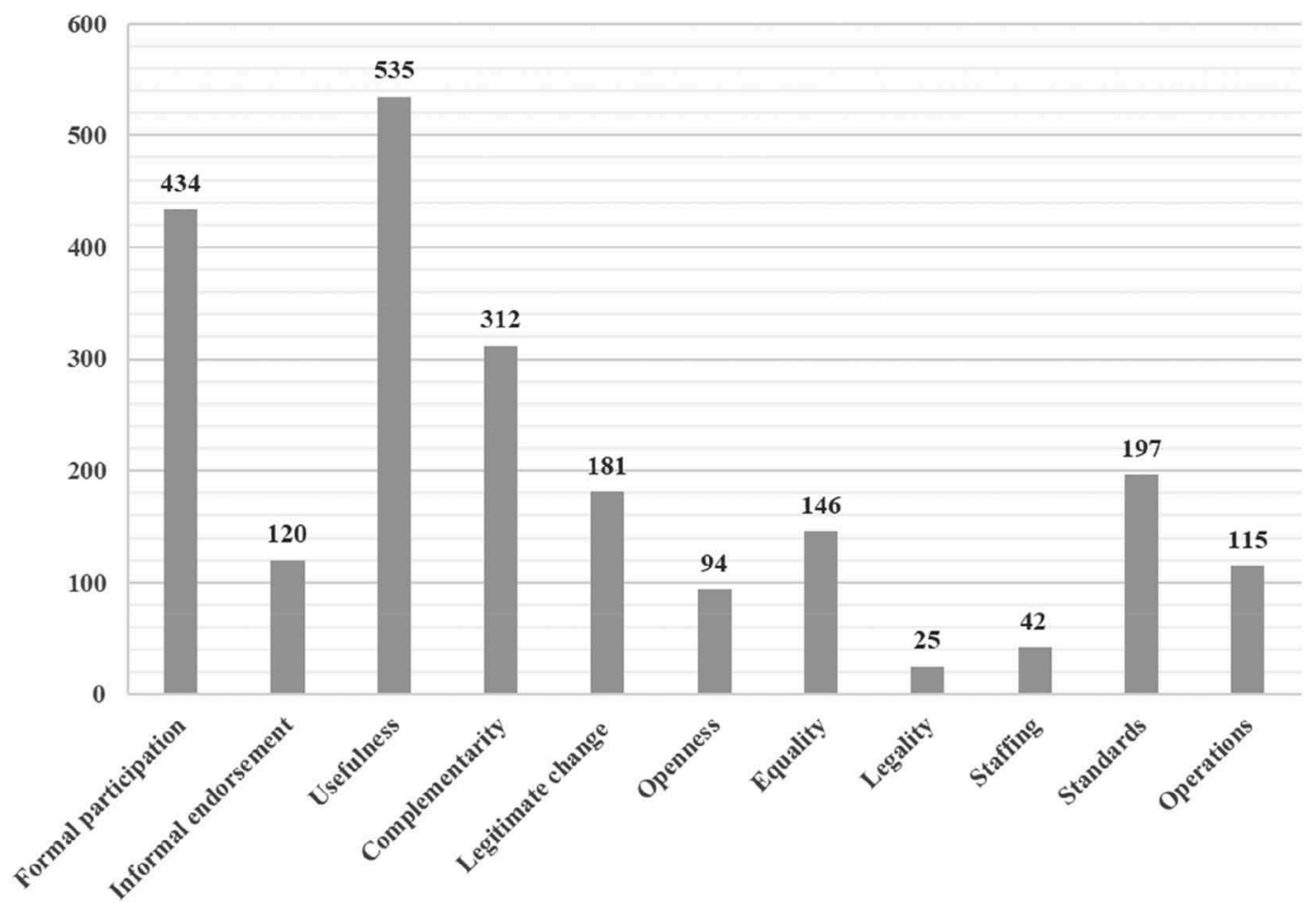

Figure 2. Number of legitimacy claims.

Britain, France, Germany, and Italy to join the China-proposed AlIB, as no country would want to miss opportunities that come with the rapid economic development in Asia. ${ }^{63}$

As for the not-so-negligible number of references to the AllB's (ability to institute) high standards, it can be attributed in some degree to the vigorous framing contest between China and AllB skeptics on the bank's governance/lending standards, and the normative grounds on which third countries justified their decision to participate in the bank. As shown earlier, the official reason given by the US and Japan for non-participation was their doubt as to whether the China-sponsored bank would institute stringent standards. In response, Beijing repeatedly assured that the new lender would 'uphold high standards and follow international rules in its operation, policies and management to ensure efficiency and transparency. ${ }^{64}$ The issue of standards was equally an important consideration for states seeking AllB membership, since they would be better positioned to shape the governance structure and lending standards of the AllB from the inside. For example, in the statement issued by Norway upon joining, the Scandinavian country pledged to help ensure that 'the AllB embodies the best standards of governance, accountability and transparency. ${ }^{65}$ Notwithstanding the considerable number of references to standards, most of them were eclipsed by the high-frequency articulations that fall under the institutional/external dimension, thus the relatively low weight of performance dimension.

\footnotetext{
${ }^{63 ` T h a i ~ b a n k e r ~ c a l l s ~ j o i n i n g ~ A I I B ~ i r r e s i s t i b l e ~ t r e n d ', ~ C h i n a ~ D a i l y, ~(18 ~ M a r c h ~ 2015), ~ a v a i l a b l e ~ a t: ~ w w w . c h i n a d a i l y . c o m . c n / b u s i n e s s / ~}$ 2015-03/19/content_19853697.htm (accessed 5 May 2017).

${ }^{64 \prime}$ AllB agreement signed, China-led bank takes key step forward', Xinhua, (29 June 2015), available at: www.xinhuanet.com/ english/2015-06/29/c_134365586.htm (accessed 10 May 2017).

${ }^{65}$ 'Norway confirms intention to join China-proposed AllB', Xinhua, (1 April 2015), available at: www.xinhuanet.com/english/ 2015-04/01/c_134114167.htm (accessed 10 May 2017).
} 


\section{Finding (3): most legitimacy claims reached a peak in March 2015}

This sub-section takes one step further and looks at the evolution of the 11 legitimacy claims over time. Overall, the AllB's development was marked by three key events: first, the signing of the Memorandum of Understanding (MoU) by 21 states on 24 October 2014; second, the decision of the UK to apply for membership on 12 March 2015-first major Western power to do so and prompted many to follow; third, the official launch in January 2016, marking the start of actual operation. The analysis here focuses on the period from the signing of the MoU till the official launch (October 2014-January 2016), arguably the most critical period for AllB legitimation. ${ }^{66}$ As illustrated in Figure 3, references to most claims peaked in March 2015. This includes all the claims under the institutional and external dimensions (formal participation, informal endorsement, usefulness, complementarity and legitimate change), openness and high standards.

The result is undoubtedly correlated to the uneven distribution of texts over time, and specifically, the surge in media coverage between 12 March 2015-when the UK announced its decision, and 31 March 2015-the cut-off date for joining as a founding member. The UK's decision was a turning point, as it prompted a host of US allies in Europe and Asia to follow suit. Underlying the seemingly surprising announcement was the rational calculations of the conservative government to forge closer economic ties with China and further benefit its financial sector, and secure more business opportunities for British companies in Asia's prodigious infrastructure market. Defying warnings from Washington, London's decision drew extensive attention from Chinese state (and foreign) media. Chinese state media published a total of 169 texts in

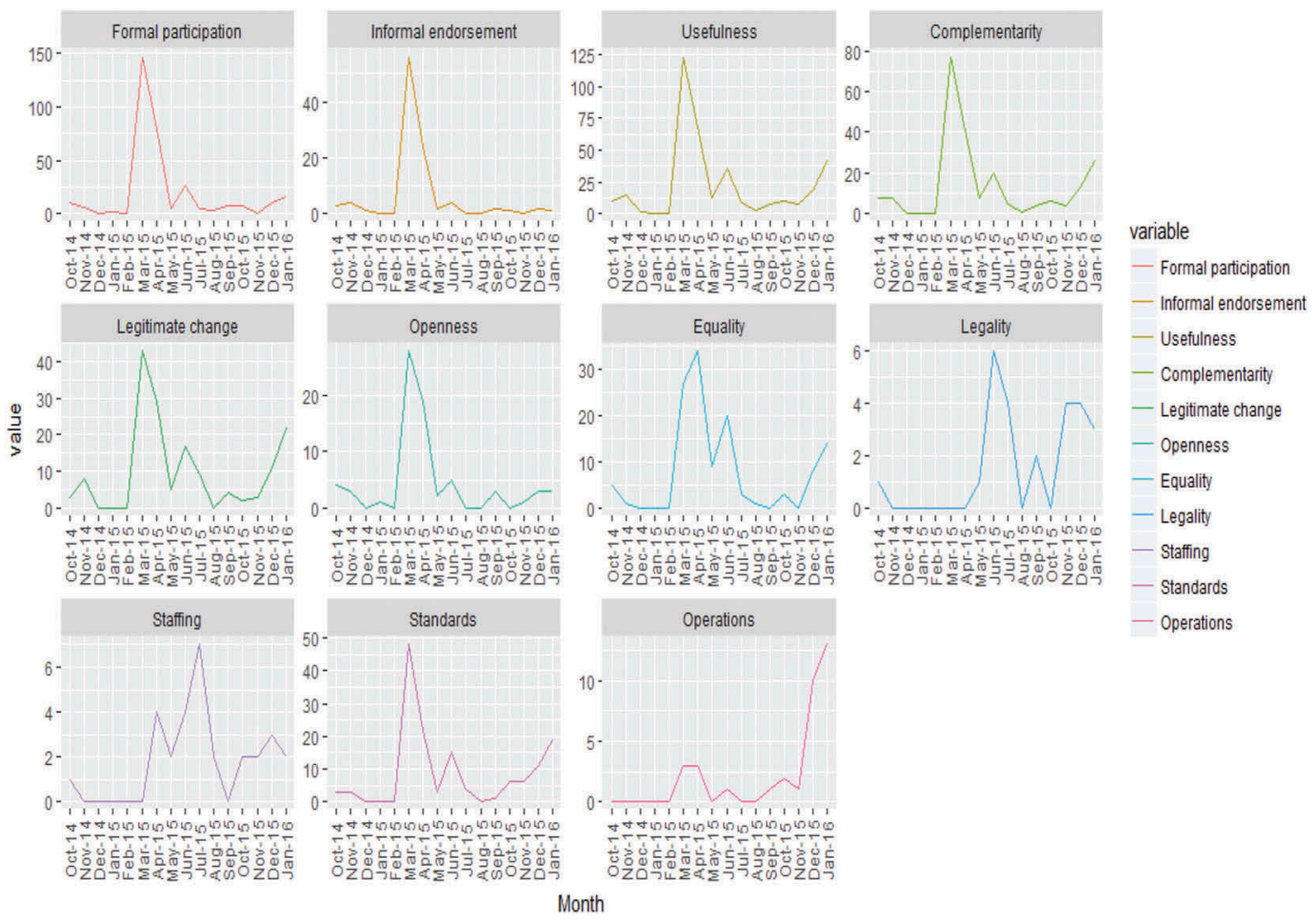

Figure 3. Distribution of legitimacy claims over time (October 2014-January 2016).

\footnotetext{
${ }^{66}$ The supplemental file shows the evolution from February 2016 till June 2017. The timeframes before October 2014 and after June 2017 were left out of this part of analysis due to the rather small number of articles.
} 
this timeframe alone, most of which dwelled upon the decisions of third countries to join or shift position. Facing the strong interest in the AllB following the decisions of leading European powers and the 'turnabout' of the US, Chinese state media responded by stressing the AllB's openness and commitment to high standards, apart from playing up the bank's growing membership, usefulness and complementarity.

\section{Concluding remarks}

This study is designed to illuminate the rhetorical efforts of Chinese state media to legitimate the AllB to the global community. To this end, it built an analytical framework of legitimacy encapsulating four dimensions: external, institutional, procedural and performance, further substantiated by concrete legitimacy claims on 11 indicators: formal participation, informal endorsement, usefulness, complementarity, legitimate change, openness, equality, legality, staffing, standards and actual operation. Grounded on this purpose-built framework, an in-depth content analysis of 730 AllB-centric news texts revealed three main findings. First, out of the four dimensions, institutional legitimacy and external recognition were much more salient in the legitimating discourse than procedural and performance legitimacy. Second, among the 11 legitimacy claims, the bank's usefulness, broad membership and support, complementarity and (commitment to) high standards were most frequently mentioned. Third, the rhetorical legitimation of Chinese state media greatly intensified in the wake of the UK's decision to join.

The study has some implications for our understanding of the AllB, Chinese state media and Chinese foreign policy. First, an overwhelming majority (about 90\%) of the sample presented the AllB in an absolutely positive light, serving to augment and reinforce Chinese official discourse on the new institution. Second, the significant number of references to the AllB's usefulness, complementarity, expanding membership and high standards underlines the unambiguous message that China intended to get across via its state media. Namely, the AllB is useful, complementary, up-to-par and well-received by the international community. Arguably, this was Beijing's response to the concerns raised (either officially or unofficially) by Washington/Tokyo and will in all likelihood become a baseline against which to measure the AllB's future performance. Third, the surge in media attention and the peaking of most claims during the course of March 2015 attest both to the intensity of the frame contest on the AllB ensuing from the UK's decision and the relative obscurity of the China-led initiative therebefore, at least seen through the lens of media.

Fourth, rhetorical legitimation of the AIIB, an institution viewed by some as an example of China's 'emerging institutional statecraft', can shed some light on how China tries and will try to justify its institution-building behavior. ${ }^{67}$ That is, Beijing seeks foreign support and participation by underlining the benefits or necessity of the parallel structures and promising their cooperative stance and compliance with international standards, all the while pointing to the imperative to revise the current world order. Once successful, participation/endorsement by foreign actors, which in and of itself contributes to boosting legitimacy, is interpreted and shown as an approval of the alternative structures and used to encourage more participation. In fact, similar legitimating discourse has been crafted and articulated by Chinese officials and state media to the global community as regards other recent China-led initiatives, notably the BRI. As the initiative unfolds in full swing (and the emergence of teething problems with some projects) and Beijing seeks to garner more foreign participation/endorsement, the issue of legitimacy has once again come into the foreground. Concerns have been raised about the standards of BRI projects and the motivations of China. Given the similarity between the two initiatives (both as China-led institutional arrangements faced with contestation, politicization and mediatization), the framework developed and the insights drawn herein can be useful for analyzing China's legitimation of the BRI.

\footnotetext{
${ }^{67}$ Ikenberry and Lim, 'China's emerging institutional statecraft'.
} 
The study has limitations. First, as noted in the introduction, it focuses on the legitimacy claims made by Chinese state media. It does not address the question of effectiveness-how these claims were received by intended audiences-a question that merits to be accounted for in its own right. Nor does it pretend to be exhaustive, as there are other avenues available for studying China's AllB legitimation. Second, the four-dimensional legitimacy framework and the 11 legitimacy claims, in particular, are to a large extent tailor-made for this research. As a result, the case-sensitive analytical apparatus will have to be adapted to better suit the needs of studies on the legitimation of new institutions to the existing global system.

\section{Disclosure statement}

No potential conflict of interest was reported by the authors.

\section{Funding}

The work was supported by China Scholarship Council [grant no. 201507650009].

\section{Notes on contributors}

Hai Yang is a doctoral researcher at the Leuven International and European Studies Institute in KU Leuven. His research focuses on two China-backed multilateral initiatives-the Asian Infrastructure Investment Bank and the Belt and Road Initiative, with particular attention to China's rhetorical legitimation of the initiatives and the external perception thereof. His works have been published in The Pacific Review, Asia Europe Journal, and Chinese Political Science Review.

Stephan Keukeleire is professor at the Leuven International and European Studies Institute in KU Leuven, visiting professor at College of Europe, and Jean Monnet Chair in European Foreign Policy. His works have been published in Journal of Common Market Studies, Cooperation and Conflict, Journal of European Public Policy, and Global Governance, among others.

\section{ORCID}

Hai Yang (D) http://orcid.org/0000-0002-9719-1813

Stephan Keukeleire (iD http://orcid.org/0000-0002-4030-0265 